Rev. Saúde públ., S. Paulo

$16: 144-8,1982$

\title{
ESQUEMA REDUZIDO DE VACINAÇÃO ANTI-RÁBICA HUMANA PRÉ-EXPOSIÇÃO E AVALIAÇÃO DE DOSES ANUAIS DE REFORÇO
}

\author{
Esther Luiza Bocato Chamelet* \\ Murillo Pacca de Azevedo* \\ Silvana Regina Favoretto** \\ Sosthenes Vital de Kerbrie* \\ Luiza Terezinha Madia de Souza *
}

\begin{abstract}
CHAMELET, E.L.B. et al. Esquema reduzido de vacinacâo anti-rábica humana pré-exposiçăo e avaliaçăo de doses anuais de reforço. Rev. Saúde públ., S. Paulo, $16: 144-8,1982$.

RESUMO: São apresentados os resultados do emprego de esquema de vacinação anti-rábida humana pré-exposição, constituído de 3 doses de vacina tipo Fuenzalida-Palacios administradas a 165 pacientes em dias alternados, mais uma dose de reforço no $30^{\circ}$ dia após a dose inicial. Os títulos de anticorpos foram determinados por prova de soroneutralização em amostras de sangue colhidas antes, 30 e 40 dias após administração da primeira dose. Verificou-se que no $30^{\circ}$ dia, $74,6 \%$ dos pacientes apresentaram anticorpos neutralizantes no soro, valor que se elevou a $98,1 \%$ no quadragésimo dia, o que mostra a eficácia do esquema em relação à resposta imunitária em tempo relativamente curto e a importancia da dose de reforço como estímulo à produção de anticorpos. Nos pacientes submetidos às doses anuais de reforço num periodo de 10 anos, verificou-se aumento gradual da presença de anticorpos antes da administração da dose de reforço subsequiente, até atingir valores de $100 \%$. Face aos resultados obtidos foi sugerido que as doses de reforço sejam administracias a intervalos de tempo maiores e precedidas da titulagem de anticorpos a fim de se avaliar da necessidade ou não de sua administração.
\end{abstract}

UNITERMOS: Raiva, vacina. Vacinação.

\section{INTRODUCGA}

A imunização anti-rábica pré-exposição é imperativa a grupos profissionais cuja atividade os obrigue à permanência em áreas de alto risco. Entre esses indivíduos expostos estão os pesquisadores que manu. seiam o vírus rábico em laboratórios, veterịnários, laçadores de animais, naturalistas. entre outros.
A vacina deverá conter elevado teor imunogênico para que o esquema preconizado possa revelar alta resposta imunitária com pequenas quantidades de antigeno, estando ainda relativamente livre de fatores encefalitogênicos $\mathbf{4 , 7 , 9}$.

É recomendável que o ingresso na área de alto risco ao contágio só se processe após

* Do Instituto Pasteur da Secretaria de Estado da Saúde de São Paulo - - Av. Paulista, 393 . 01311 - São Paulo, SP - Brasil.

* Da Fundação do Desenvolvimento Administrativo - Rua Cristiano Viana, 428 -. 05411 - São Paulo, SP - Brasil. 
CHAMELET, E.L.B. et al. Esquema reduzido de vacinação anti-rábica humana pré-exposição e avaliaçăo de doses anuais de reforco, Rev. Saúde públ., S. Paulo, 16:144-8, 1982.

avaliação sorológica, razão pela qual o esquema a ser indicado deverá propiciar resposta no menor tempo possivel.

O esquema recomendado por autores norte-americanos, empregando a vacina DEV, consiste na administração de 2 doses de $1 \mathrm{ml}$ por via subcutânea $\mathrm{a}$ intervalos de 30 dias, com uma dose de reforço 6 meses após $3,6,10$. Resposta mais rápida pode ser obtida pela administração de 3 doses de $1 \mathrm{~m}$ ! a intervalos semanais com reforço adminis. trado após 6 meses 1,3,6,10,12. Em ambos os casos as determinações para a presença de anticorpos circulantes far-se-ão 3 a 4 semanas após a administração da dose de reforço. Fuenzalida 4 obteve melhores resultados empregando vacina preparada a partir de cérebro de camundongos recém-nascidos num esquema que consiste na administração de 3 doses de $2 \mathrm{ml}$ por via subcutânea 4

De acordo com a Comissão de Feritos em Raiva da OMS ", uma vez verificada a resposta imunitária ao esquema inicial, os pacientes deverão receber reforços de vacina a intervalos de 1 a 3 anos, enquanto permanecerem na área de risco.

o presente trabalho tem por objetivo relatar os resultados obtidos na imunização anti-rábica pré-exposição ao contágio com a vacina tipo Fuenzalida-Palacios em esquema reduzido, bem como avaliar os efeitos das revacinações anuais e a presença de anticorpos num período de dez anos.

\section{MATERIAL E METODOS}

Pacientes — Foram submetidos à vacinação anti-rábica, com esquema reduzido, $165 \mathrm{pa}^{-}$ cientes, profissionais com atividade em área de alto risco, na maioria do sexo masculino e com idades variáveis entre 18 e 48 anos. Os que permaneciam na área de risco eram submetidos a doses anuais de reforço.

Vacina - Empregou-se a vacina do tipo Fuenzalicia-Palacios produzida pelo Instituto Butantan, que consiste numa suspensão a $2 \%$ de cérebro de camundongos lactentes inoculados com virus amostra Pasteur, inati- vada por irradiação Ultra Violeta tendo como conservadores ácido fênico a $0.1 \%$ e Timerosol a 1/10.000. Todos os lotes de vacina foram submetidos à prova de potência de acordo com o método de Habel 5 tendo sido os valores encontrados, sempre superiores a $100^{6.0 \mathrm{DL}_{50}}$.

Esquema de vacinação - Foram administrados em dias alternados, $1 \mathrm{ml}$ de vacina por via subcutânea num total de 3 doses : uma dose de reforço 30 dias após o início da vacinação. Doses anuais subseqüentes (1 $\mathrm{ml})$ foram administradas e os pacientes cibservados no periodo de 1972 a 1981.

Soro - Amostras de sangue foram colhidas por punção venosa nos dias 0,30 e 40 . da vacinação bem como antes e 10 dias após cada dose anual de reforço.

As amostras de soro separadas foram conservadas a $-20^{\circ} \mathrm{C}$ até o momento da titulagem de anticorpos realizada pela técnica de soro-neutralização ${ }^{2}$ com os cálculos cfetuados pelo método de Reed e Muench ${ }^{11}$.

\section{RESULTADOS}

A Tabela apresenta os valores dos títulos cm anticorpos anti-rábicos dos pacientes submetidos à vacinação pré-exposição ao contágio.

Nenhum dos pacientes havia sido submetido à vacinação anti-rábica anterior e assim não foi verificada presença de anticorpos nas amostras dos soros colhidos antes da administração do antígeno. (título $<5$ no dia zero).

Das amostras colhidas após a administração das três primeiras doses (dia 30 do inicio da vacinação), $123(74,6 \%)$ apresentaram titulos em niveis que variaram entre 5 a 625 , das quais 56 (34\%) com titulos superiores a 25.

$\mathrm{Na}$ coleta efetuada no quadragésimo dia, 10 dias após a dose de reforço, o percentual de resposta elevou-se para 98,1\% (150 pacientes) sendo que apenas 3 pacientes deixaram de responder. 
CFAMELET, E.L.B, et al. Esquema reduzido de vacinação anti-rábica humana pré-exposição e avaliação de doses anuais de reforço. Rev. Saúde públ., S. Pạulo, 16:144-8, 1982.

T A B E L A

Resposta imunitária obtida pelo esquema de vacinação anti-rábica de $3+1$ doses.

\begin{tabular}{|c|c|c|c|c|c|c|}
\hline \multirow[b]{2}{*}{ Título } & \multicolumn{2}{|c|}{ Dia zero } & \multicolumn{2}{|c|}{ Dia 30} & \multicolumn{2}{|c|}{ Dia 40} \\
\hline & $\begin{array}{l}\text { Número } \\
\text { pacientes }\end{array}$ & $\%$ & $\begin{array}{l}\text { Número } \\
\text { pacientes }\end{array}$ & $\%$ & $\begin{array}{l}\text { Número } \\
\text { pacientes }\end{array}$ & $\%$ \\
\hline$<$ & 165 & 100,0 & 42 & 25,4 & 3 & 1,9 \\
\hline $5 \mid-25$ & 0 & 0.0 & 67 & 40,6 & 89 & 58,2 \\
\hline $25-125$ & 0 & 0.0 & 41 & 24,9 & 37 & 24,2 \\
\hline $125 i-625$ & 0 & 0.0 & 15 & 9.1 & 24 & 15,7 \\
\hline Total & 165 & 100,0 & 165 & 100,0 & 153 & 100,0 \\
\hline
\end{tabular}
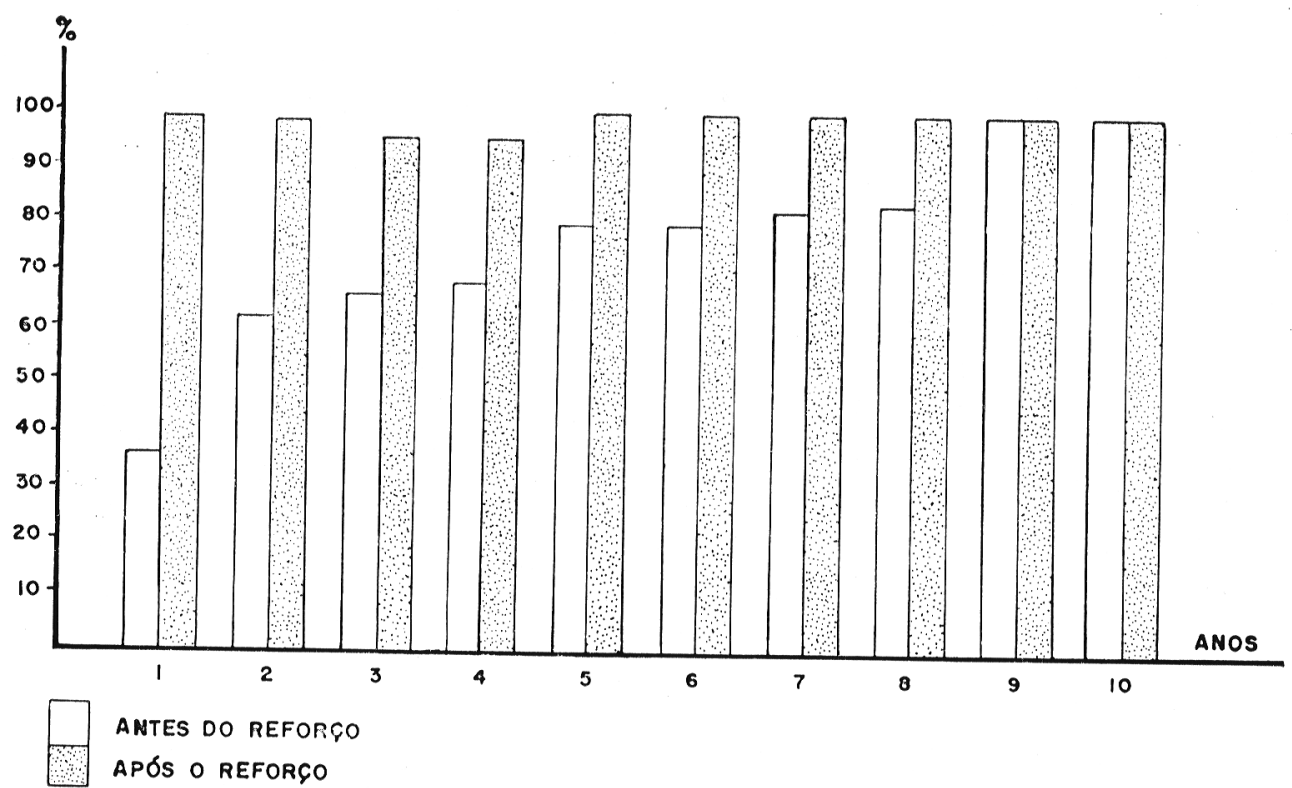

Fig. - Percentual de resposta imunitária observada antes e após reforços anuais, em pacientes que receberam o esquema básico de imunização pré-exposição. (1972-1981).

Como se pode verificar posteriormente. esses mesmos pacientes continuaram a não responder ao antigeno em termos de produção de anticorpos neutralizantes, após reforços anuais efetuados durante 4 anos consecutivos, razão pela qual foram afastados da área de alto risco.

Após o esquema básico de imunização, foram administrados reforços anuais aos pacientes que permaneceram nas áreas de 
CHAMELET, E.L.B. et al. Esquema reduzido de vacinação anti-rábica humana pré-exposição e avaliação de doses anuais de reforço. Rev. Saúde públ. S. Paulo, 16:144-8, 1982.

super exposição e a figura nos mostra os percentuais dos pacientes que apresentaram titulo de anticorpos antes e depois dos respectivos reforços.

Verifica-se que após o primeiro ano da aplicação do esquema em estudo, $37,1 \%$ dos pacientes ainda apresentam niveis de anticorpos detectáveis, indice esse que se eleva gradualmente nos anos subsequientes, atin. gindo o percentual de $80 \%$ no quinto ano.

Entre o quinto e o oitavo ano, a presença de anticorpos é observada mesmo antes da aplicação da dose de reforço em 80 a $90 \%$ dos pacientes, atingindo valor de $100 \%$ apos o nono ano.

\section{DISCUSSÃO E CONCLUSŌES}

Os resultados obtidos na vacinação com () esquema reduzido indicam a eficácia do mesmo quando se trata de imunização pré-exposição, utilizada com o objetivo de desencadear no sistema imuno competente, uma resposta primária. O esquema em questão propiciou alto indice de resposta em curto periodo.

Dos pacientes observados neste esquema de vacinação verifica-se que em 3 deles $(1,9 \%)$, mesmo após o reforço, a sorologia permaneceu negativa, fazendo supor ausência de resposta humoral especifica ou yue esta se fez em niveis tão baixos a ponto de não ser detectável.
Os reforços são consdierados imprescindíveis nos esquemas de imunização pré-exposição ao contágio $1,4, \$, 1 \%$. Os nossos resultados mostram que $25,4 \%$ dos pacientes que deixaram de responder ao esquema básico de 3 doses apresentaram resposta após reforço em niveis elevados de anticorpos.

A observação dos indices de anticorpos rábicos realizados anualmente nos pacientes submetidos à imunização básica mostra que após o primeiro ano, $37,1 \%$ dos mesmos nantêm resposta imune antes da administração da dose anual de reforço, sendo que os demais pacientes respondem rapidament à dose de reforço mostrando a persistência da memória imunológica através da mobilização de suas células inunocompetentes.

A partir do segundo ano e até o oitavo, " número de pacientes, cujos títulos em anticorpos permanecem em niveis detectáveis antes da administração da dose subsequiente de reforço, cresce gradualmnte, até atingir o nível máximo $(100 \%)$ a partir do nono ano.

A fim de que se possa reduzir o nủmero de doses de vacina anti-rábica deve-se recomendar, de acordo com os resultados do presente trabalho, que os reforços anuais sejam administrados somente após o estudo sorológico individual, principalmente a partis do segundo ano quando o número de pacientes $(62,8 \%)$, cujos titulos permanecem em niveis altos, é significativamente elevado. 
CHAMELET, F.L.B. el al. Esquema reduzido de vacinação anti-rábica humana pró-exposiłãu st avaliação de doses anuais de reforço. Rev. Suxide pübl., S. Paulo, 16:144-8. 1982.

CHAMELET, E.I.B. et al. IA reduced schedule for anti-rabic pre-exposure vaccination in humans and annual assessment boostur dosesl. Her. Saúde públ., S. Paulo. $16: 144-8,1982$.

ABSTRACI: A reduced schedule for a pre-exposure anti-rabic immunization of humans with 3 doses of $1 \mathrm{ml}$ of Fuenzalida-Palacios type vaccine administered on alternate days, plus one booster 30 days after the first dose, was related. The blood samples were collected on the $0,30 \ldots$ and 40 . day after the first vaccine dose and the antibody titration was performed by serum neutralizing test. It was observed that $74.6 \%$ of the patients presented serum neutralizing antibndies on the $30 \mathrm{t}$ day and $98.1 \%$ on the 4011 day, demonstrating the efficacy of this reduced schedule in stimulating the antibody response in a short time. The importance of a booster dose was emphasized. In the patients submitted to annual boosters over a period of 10 years, a gradual increase in the number of patients with anti-rabic antibodies before the subsequent booster dose was observed, reaching the level of $100 \%$ in the 911 year. It was suggested that the booster doses be administered at longer intervals and after antibody titration in order to evaluate the need for the administration of the booster dose.

UNITERMS: Rabies vaccine. Vaccination.

f. ANDERSON, G.R. et al. Avian embryo xabies immunization. 1. Duck-embryo vaccine adwhinistered intradermally in man. Amer J. Hyo., $71: 158-67, \quad 1960$.

2. ATANASIU, P. Titrage des anticorps ra. biques sur les séruns humains. Bull Off. int. Epiz., 67:383-7, 1967.

3. COREY, L. et al. Treatment of person. exposed to rabies, $J$, Amer. med. Ass., 232: $: 272-6, \quad 1975$.

4. HUENZALIDA, E. Hman pre-exposure rabies immunization with suckling mouse brain vaccine. Bull. Wld Hlth Org., 46 $561-3,1972$.

5. HABEL, K. Prueba de potencia de Habei. In: Kaplan, M.M. \& Koprowski, H .Li rabia: técnicas de laboratorio. 3" ed. Ginebra, OMS, 1976. p. 290-1.

6. HATTWICK, M.D. et al. Pre-exposur rabies prophilaxis. $J$. Amer, net med Ass., 160:136-8, 1972.
7. HELD, J.R. et al. Imunización humana con vacuna antirrabica de cerebro do ratón lactante. Bol. Ofic sanit, panamer. $73: 565-75,1972$.

8. MOREIRA. E.C. et al. Imunización preventiva contra la rabia humana. Bol. ofic. sanit. panamer., 73:110-6. 1972.

9. ORGANISATION MONDIALE DE LA SANTE. Comité d'Experts de la Rage. Genève, 1972. 6" rapport. Genève. 197\%. (Rapp. tecn. Ser. 523).

10. PLOTKIN, S.A. et al. Prevention of mabies in man. $J$. infect. Dis., 123:227-40, 1971.

11. REED, L.J. \& MUENCH, H. A simple method of estimating fifty per cent end -points. Amer. J. Hyg., 27:493-7. 1938.

12. RUSSEL, L.H. et al, Accidental exposure of veterinary students to rabies, $J$. Amer. vet. med. Ass., 171:1184-6. 1977.

Recebido para publicação em 06/L1/1981 Aprovado para publicagdo em 14/04/1982 